\title{
To estimate the incidence, etiology and risk factors of wound infections in women who undergoes cesarean section at Kilpauk Medical College Hospital: a prospective study
}

\section{Jayalakshmi Subramani*, Devika Perumal}

Department of Obstetrics and Gynecology, Government Dharmapuri Medical College and Hospital, Dharmapuri, Tamilnadu, India

Received: 17 March 2017

Accepted: 30 March 2017

\section{*Correspondence:}

Dr. Jayalakshmi Subramani,

E-mail: Jayaravi.dr@gmail.com

Copyright: (C) the author(s), publisher and licensee Medip Academy. This is an open-access article distributed under the terms of the Creative Commons Attribution Non-Commercial License, which permits unrestricted non-commercial use, distribution, and reproduction in any medium, provided the original work is properly cited.

\section{ABSTRACT}

Background: Wound infections following caesarean section (or) gynaecologic surgery is a common complication that accounts for significant extension of hospital stays.

Methods: This is a prospective analytical study, conducted in the department of obstetrics and gynaecology, kilpauk medical college, Chennai from Januray 2013 to November 2013. All cases who underwent ceaserean section were included in the study. Analysis was done in the form of percentages and proportions and represented as tables where necessary.

Results: A total of 700 cases were analysed. The incidence of wound infections after caesarean section in this study was $8.14 \%$. Study confirms that risk factors like anemia, chorioamnionitis; PROM, obstructed labour, preeclampsia, increased surgical time, increase BMI poses risk for wound complications. Whereas chorioamnionitis $(66 \%)$ and obstructed labour (66\%) showed increased risk for wound complications.

Conclusions: Correcting malnutrion, anemia, stabilizing diabetes and eradicating all infection such as urinary tract infection, proper preparation of skin, proper surgeons scrubbing and using proper surgical technique can decrease the risk of postoperative wound infection.

Keywords: Ceasarean section, Surgery, Wound infection

\section{INTRODUCTION}

Wound complications following caesarean section or gynecologic surgery is a common complication that accounts for significant extension of hospital stays and adds considerable cost to hospital bills. ${ }^{1}$

The infection rate following caesarean delivery ranges from 3 to $15 \%$ with an average of about $6 \%$. But, when prophylactic antimicrobial was given the incidence was less than $2 \% .^{2}$

Before the mid-19th century, postoperatively patients developed irritative fever, purulent discharge from their incisions, sepsis and rarely death. ${ }^{3}$

The Surveillance of SSIs brings about the awareness to the present day modern surgeon about the proper use of prophylactic and therapeutic antibiotics and strict aseptic technique and adequate monitoring and support with novel surgical and pharmacological as well as nonpharmacological aids.

Many a studies have been conducted regarding the SSIs under the guidelines provided by CDC. With the current knowledge of SSIs and their attributable risks, under the 
guidelines of CDC a clinical study of wound infection following caesarean section occuring in Kilpauk Medical College, Chennai has been undertaken to analyse the risks involved. Objectives of present study are:

- To find the incidence of wound infections after caesarean section.

- To study the association of risk factors in post caesarean wound infections like anemia, hypertension, diabetes, chorioamnionitis, PROM, obstructed labour, BMI, socioeconomic status, duration of surgery and type of skin incision.

- To evaluate important factors in the prevention of post caesarean wound infection.

\section{METHODS}

It is a prospective study carried out at Kilpauk Medical College Hospital, Chennai from January 2013 to November 2013 with sample size of 700 patients who underwent lower segment caesarean section.

Various risk factors like BMI, anemia, hypertension, DM, PROM, chorioamnionitis, obstructed labour were taken into consideration. Operative characteristics like duration of the procedure, type of abdominal incision, skin closure and their influence on wound complication was studied.

In post-operative period patients were monitored for signs of development of wound infection such as rise of temperature, nature of discharge from operative site, wound erythema and induration. Bacteriological studies were carried in wound infected cases. Wound complication were managed appropriately by using antibiotics, daily dressing or surgical resuturing.

\section{Inclusion criteria}

All women delivered by caesarean section.

\section{Exclusion criteria}

All women who delivered vaginally.

\section{RESULTS}

Among 700 cases, 57 cases developed wound infections which accounted for $8.14 \%$ (Table 1).

Table 1: Incidence of wound infections.

\begin{tabular}{|lll|}
\hline Complications & No. of cases & $\%$ \\
\hline Wound infection & 57 & 8.14 \\
\hline No wound infection & 643 & 91.86 \\
\hline Total no of cases & 700 & 100 \\
\hline
\end{tabular}

Commonest type of wound infection was superficial wound infection $(56.14 \%)$. None of the patients developed fascial dehiscence or hematoma (Table 2) $87.5 \%$ of the wound infections were seen in patients aged 31-35 years and $50 \%$ were seen $>35$ years (Table 3 ).

Table 2: Type of wound infection.

\begin{tabular}{|lll|}
\hline Complications & $\begin{array}{l}\text { No. of } \\
\text { cases }\end{array}$ & Percent \\
\hline Superficial wound Infection & 32 & 56.14 \\
\hline Superficial wound breakdown & 25 & 43.85 \\
\hline
\end{tabular}

Table 3: Wound infections with reference to age.

\begin{tabular}{|lllll|}
\hline $\begin{array}{l}\text { Age } \\
\text { (years) }\end{array}$ & $\begin{array}{l}\text { Total no. } \\
\text { of cases }\end{array}$ & $\begin{array}{l}\text { Wound } \\
\text { infection }\end{array}$ & $\begin{array}{l}\text { \% of wound } \\
\text { infection }\end{array}$ \\
\hline$\leq 20$ & 69 & 2 & 67 & 2.89 \\
\hline $21-25$ & 434 & 14 & 420 & 3.2 \\
\hline $26-30$ & 163 & 12 & 151 & 7.36 \\
\hline $31-35$ & 32 & 28 & 4 & 87.5 \\
\hline$>35$ & 2 & 1 & 1 & 50 \\
\hline Total & $\mathbf{7 0 0}$ & $\mathbf{5 7}$ & $\mathbf{6 4 3}$ & $\mathbf{1 0 0}$ \\
\hline
\end{tabular}

According to pearson chi-square test, p-value is 0.047 , statistically significant.

Table 4: Wound infections with reference to the type of caesarean section.

\begin{tabular}{|c|c|c|c|c|}
\hline \multirow[t]{2}{*}{ Type } & \multirow{2}{*}{$\begin{array}{l}\text { Total no. } \\
\text { of cases }\end{array}$} & \multicolumn{2}{|c|}{$\begin{array}{l}\text { Wound } \\
\text { infection }\end{array}$} & \multirow[t]{2}{*}{$\%$} \\
\hline & & Yes & No & \\
\hline Elective & 82 & 4 & 78 & 4.8 \\
\hline Emergency & 618 & 53 & 565 & 8.6 \\
\hline Total & 700 & 57 & 643 & \\
\hline
\end{tabular}

According to pearson chi-square value is 0.382 and $p$ value is 0.826 , statistically in significant.

It is clearly shown that wound infection is more common in emergency LSCS (8.6\%) (Table 4). The various risk factors which contribute to the wound infections are anaemia (16.2\%), hypertension (10.2\%), DM (10.8\%), obstructed labour $(66 \%)$, chorioamnionitis $(66 \%)$ and PROM (25.3\%) (Table 5).

Staph aureus and E. coli are the commonly obtained organisms (Table 6). Staph aureus is highly sensitive to Gentamycin and E. coli sensitive to Amikacin. Out of 57 cases, 25 cases were managed by resuturing, 32 cases were managed by daily dressing and antibiotics (Table 7). Of the 700 cases, 1 out of 30 from socioeconomic status class $3(3.3 \%), 9$ out of 361 from socioeconomic status class 4 $(2.5 \%)$ and 47 out of 309 from socioeconomic status class $5(15.2 \%)$ developed wound infection. It is clearly shown that wound infection is common in low socioeconomic status. Of the 700 cases, 303 were primi and 397 were multi. $32(10.6 \%)$ cases of primi and $25(6.3 \%)$ cases of the multi developed wound infection. PrimiPara is more prone for wound infection. Obese and morbidly obese are more prone for infection. Wound infections are common in pfannensteil incision. $8.2 \%$ of the patients developed 
wound infection with pfanneinsteil incision compared to $7.7 \%$ with midline vertical incision.

Table 5: Wound infections with reference to patient characteristics.

\begin{tabular}{|lllllll|}
\hline Characteristics & Total no. of cases & \multicolumn{2}{c}{ Wound infection } & \% of wound & Pearson chi & P \\
infection & No & $\begin{array}{l}\text { Pquare value } \\
\text { value }\end{array}$ \\
\hline Anaemia & 111 & 18 & 93 & 16.2 & 11.495 & 0.001 \\
\hline Hypertension & 127 & 13 & 114 & 10.2 & 0.909 & 0.216 \\
\hline Diabetes mellitus & 93 & 10 & 83 & 10.8 & 0.977 & 0.211 \\
\hline PROM & 95 & 24 & 71 & 26.3 & 43.112 & 0.000 \\
\hline Obstructed labour & 6 & 4 & 2 & 66.7 & 27.712 & 0.000 \\
\hline Chorioamnionitis & 3 & 2 & 1 & 66 & 13.796 & 0.000 \\
\hline
\end{tabular}

When the duration of operation was more than 60 minutes, $71.4 \%$ of women developed wound infection as compared to $33.3 \%$ and $6.6 \%$ with the duration of operation between 45-60 min and less than 45 minutes respectively. As the duration of surgery increases, wound infection rate increases.

Table 6: Commonly obtained organisms.

\begin{tabular}{|ll|}
\hline Organism & No. of cases \\
\hline Staphylococcus & 18 \\
\hline E. coli & 10 \\
\hline Pseudomonas & 6 \\
\hline Klebsiella & 9 \\
\hline Enterobacter & 4 \\
\hline No growth & 10 \\
\hline
\end{tabular}

Out of 686 patients with subcuticular suture $56(8.2 \%)$ had wound infections whereas 1 out of $14(7.1 \%)$ with mattress suture developed wound infection. Wound infection is more common in subcuticular suture. $52 \%$ of the women who received antibiotics for more than 7 days developed wound infection, whereas in patients who received antibiotics for 4-7 days and 3 days, wound infection were $5 \%$ and $0 \%$ respectively. The average hospital stay for women with no complication was 7 days. In those who had wound infections, 15 patients stayed for $>9$ days and 3 patients stayed for $>15$ days. Thus wound infection increased the hospital stay by an average of 7 days.

Table 7: Management of wound infections.

\begin{tabular}{|ll|}
\hline Management & No. of cases \\
\hline Resuturing & 25 \\
\hline Daily dressing and antibiotics & 32 \\
\hline Total & $\mathbf{5 7}$ \\
\hline
\end{tabular}

\section{DISCUSSION}

The current study was done with 700 patients with both elective and emergency LSCS during January 2013November 2013 at Kilpauk Medical College, Chennai.
The wound infection rates after caesarean section vary from $2.8-26.8 \%$ reported in literature, the incidence of wound infection in present study was $8.14 \%$. The study conducted by Mahale AR et al showed an incidence of $8.6 \% .^{4}$ In a study conducted by Tran TS et al the overall rate of post operative infection was $12.4 \%$ which was reported in prospective study of 1319 caesarean which was comparable to our study.

In a study by Mahale AR elective and emergency caesarean section did not show difference in overall wound infection rate, but in their study wound gapes were relatively more in Emergency LSCS, whereas in the present study incidence of wound infections in elective LSCS was $4.8 \%$ which is less compared to emergency LSCS $(8.6 \%)$

The incidence of wound infections in various risk factors like anemia (16.2\%), Hypertensive (10.25\%), DM $(10.8 \%)$, obstructed labour $(66 \%)$, choriamniontis $(66 \%)$, PROM $(25 \%)$ where comparable with the similar results obtained by Mahale AR study which showed chorioamnionits $(60 \%)$, obstructed labour (76\%), PROM $(20.8 \%)$ and anemia $(22 \%){ }^{4}$ In the present study Obstructed labor (66\%), Chorioamnionitis (66\%), significantly increased the wound complication rate. In comparison with other variables which were similar to the results given by Mahale AR. ${ }^{4}$

In Study conducted by Takoudes TC et al supports the clinical observation that DM is a risk factor for wound complications. ${ }^{5}$ Wound healing is compromised due to poor blood supply, neuropathy and altered immune function. ${ }^{5}$ They reported that DM is associated with 2.5fold increase (18\%) in wound complications after caesarean section. The present study showed $10.8 \%$ of wound complication rate in patient with diabetes. In a Study by Tran TS et al reported that obesity is a risk factor for wound infections. ${ }^{6}$ The risk of infection doubled for every five-unit increment of BMI because of poor vascularity of adipose tissue and dead space formation. ${ }^{5}$ In the current study it can be seen that the rate of wound infection was high in obese patients. The rate of wound 
infections was $33 \%$ in morbidly obese patients (BMI>40) and single patient in our study who was obese (BMI>30) developed wound infection.

The present study showed $8.2 \%$ of wound infection with pfannenstiel incision, $7.7 \%$ with midline vertical incision, where as in a study reported by Mahale AR showed wound infection rate was statistically more in midline $(17.17 \%)$ than in other type of incisions like pfannenstiel (14.28\%), para median (5.10\%) and Joel Cohen (Misghav ladach) $(7.48 \%) .^{4}$

In the study by Mahale AR the average hospital stay for woman with no wound complication was 6 days, woman who had wound complication stayed for 14.01 days. The average hospital stay increased by 7 days in wound complicated cases. In the present study the average duration of hospital stay for women with no wound complications was 7 days and women with wound complications stayed for more than 15 days which increased by 8 days. Tran TS et al also reported that caesareans that lasted longer than $1 \mathrm{hr}$ had 2.4 times the risk of postoperative infection. ${ }^{5}$ In the present study $72 \%$ of patients had wound infections, when the duration of operation was $>1 \mathrm{hr}$ compared to $33 \%$ and $6.6 \%$ whose duration of operation was between 45-60 min and less than 45 min respectively. Tran TS et al also showed that longer the duration of operation increases the risk of postoperative wound infections. ${ }^{6}$

The most common bacteria isolated in current study was staphylococcus aureus, the other isolates obtained were Pseudomonas Spp., Esch coli, Klebsialla, Enterobacter Spp, few patients did not have any bacterial isolates. Many others observed similar findings. In a study by Martens et al the most common pathogens cultured from infected caesarean wounds are Staphylococcus aureus, Esherichia coli and Proteus mirabilis. In another study by Roberts et al identified the most prominent pathogens as cervico vaginal flora such as ureaplasma species and mycoplasma species. $^{7}$

On the other hand others have noted milder infections caused by gram-negative organism such as E. coli and Proteus Spp. However, this is not true for suppurated wounds, particularly those caused by Staphylococcus aureus and Pseudomonas aeruginosa where a violent local inflammation and tissue destruction occur. The most common type of wound infection found in our study was superficial wound infection.

\section{CONCLUSION}

- Caesarean section has become one of the commonest surgical procedures in obstetric practice. The incidence of wound infections after caesarean section in this study was $8.14 \%$.

- Study confirms that risk factors like anemia, chorioamnionitis, PROM, obstructed labour, preeclampsia, increased surgical time, increase BMI poses risk for wound infections. Whereas chorioamnionitis $(66 \%)$ and obstructed labour $(66 \%)$ showed increased risk for wound infections.

- Wound infections increased the duration of the hospital stay, which again increased the extra financial burden both to the patients and the Hospital. The commonest organism isolated was staphylococcus aureus.

- Superficial wound infection was the commonest wound complication which was treated by daily dressing and antibiotics.

- Correcting malnutrition, anemia, stabilizing diabetes and eradicating all infection such as urinary tract infection, proper preparation of skin, proper surgeons scrubbing, and using proper surgical technique can decrease the risk of post-operative abdominal wound infection.

- Knowledge of these risk factors would help the obstetrician in avoiding these complications and help to decrease the maternal morbidity post operatively.

- Based on the sensitivity pattern of different isolates of bacteria, an empiric antibiotic therapy in post caesarean infection can be implemented.

Funding: No funding sources

Conflict of interest: None declared

Ethical approval: The study was approved by the Institutional Ethics Committee

\section{REFERENCES}

1. Sweet RL, Gibbs RS. Wound and Episiotomy infection. In: Sweet RL, Gibbs RS et al. Infections diseases of the female genital tract, 3rd ed. Baltimore:Williams Wilkins, 1995.

2. Cunningham FG, Hauth JC, Leveno KJ, Gilstrapet L, Bloom SL, Wenstrom KD. Puerperal infection. Chapter 31, Williams Obstertics, 22th ed. USA. Appleton and Lange;2005:716.

3. Mangram AJ, Horan TC, Pearson ML, Silver LC, Jarvis WR. Guideline for prevention of surgical site infection. Infect Control Hosp Epidemiol. 1999;247-78.

4. Tran TS, Jamulitrat S, Chongsuvivatwong V, Geater A. Risk factors for post cesarean surgical site infection. Obstet Gynecol. 2000;95(3):367-71.

5. Roberts S, Maccato M, Faro S, Pinell P. The microbiology of post caesarean wound morbidity. Obstet Gynecol. 1993;81:383-6.

6. Mahale AR. Caesarean section morbiditiy- a study of 1775 cases of abdominal wounds. Obsanb Gyanec. Today. 2008;8:329-31

7. Takoudes TC, Weitzen S, Slocum J, Malee M. Risk of caesarean wound complications in diabetic gestations. Am J Obstet Gynecol. 2004;191(3):958-63.

Cite this article as: Subramani J, Perumal D. To estimate the incidence, etiology and risk factors of wound infections in women who undergoes cesarean section at Kilpauk Medical College Hospital: a prospective study. Int J Reprod Contracept Obstet Gynecol 2017;6:1793-6. 